\title{
PENGUATAN PENGUASAAN KOMPETENSI FOTOGRAFI, VIDEOGRAFI DAN TATA KELOLA MEDIA SOSIAL PADA POKDARWIS PEMANIS HERITAGE, DESA WISATA BIAUNG, TABANAN, BALI
}

\author{
Desak Putu Yogi Antari Tirta Yasa ${ }^{*}$, I Putu Dudyk Arya Putra ${ }^{*}$ \\ Program Studi Produksi Film dan Televisi \\ Institut Seni Indonesia Denpasar \\ Jl. Nusa Indah, Sumerta, Kec. Denpasar Tim, Kota Denpasar, Kode Pos 80235 \\ Bali. Indonesia \\ Email: antaritirta@isi-dps.ac.id, putududyk@gmail.ang.ac.id
}

\begin{abstract}
Abstrak
POKDARWIS (Kelompok Sadar Wisata) Desa Adat Pemanis yang selanjutnya disebut sebagai Pemanis Heritage adalah bagian dari kelompok wisata Desa Wisata Budaya Biaung yang terletak di Kecamatan Penebel, Kabupaten Tabanan, Provinsi Bali yang berfokus pada wisata alam dan budaya. Permasalahan yang dihadapi oleh Pemanis Heritage adalah belum adanya logo yang menjadi identitas Pemanis Heritage, sehingga hingga saat ini Pemanis Heritage belum memiliki kop surat, stempel dan keperluan administrasi lainnya. Selain itu, media promosi yang ada di Pemanis Heritage juga belum maksimal, seperti belum adanya info grafis, sign sistem dan media promosi lainnya. Pemanis Heritage memiliki akun media sosial tetapi belum dimanfaatkan secara maksimal sebagai media promosi. Kekurangan ini terjadi akibat belum adanya SDM yang menguasai tata kelola konten media sosial, keahlian fotografi dan videografi. Berangkat dari permasalahan tersebut di atas, kegiatan pengabdian kepada masyarakat ini menawarkan solusi dengan membuatkan desain logo sebagai identitas Pemanis Heritage, memberi pelatihan kompetensi fotografi, videografi dan tata kelola konten media sosial untuk memaksimalkan promosi wisata alam dan budaya Pemanis Heritage. Luaran dari kegiatan ini adalah luaran wajib berupa artikel ilmiah yang diterbitkan dalam jurnal nasional atau artikel prosiding seminar nasional, video kegiatan, artikel pada media massa cetak/digital, serta peningkatan keberdayaan mitra di Pemanis Heritage.
\end{abstract}

Kata Kunci: media sosial, fotografi, videografi, pemanis.

\begin{abstract}
POKDARWIS (Tourism Awareness Group) Pemanis Traditional Village, hereinafter referred to Pemanis Heritage, is part of the Biaung Cultural Tourism Village tourism group located in Penebel District, Tabanan Regency, Bali Province which focuses on nature and cultural tourism. The problem faced by Pemanis Heritage is that there is no logo that is the identity of Pemanis Heritage, so that until now Pemanis Heritage does not have letterhead, stamp and other administrative purposes. In addition, the promotional media at Pemanis Heritage are also not optimal, such as the absence of graphic info, sign systems and other promotional media. Pemanis Heritage has social media accounts but has not been used optimally as a promotional medium. This shortage occurs due to the absence of human resources who master the management of social media content, photography and videography skills. Departing from the problems mentioned above, this community service activity offers a solution by developing a logo design as the identity of Pemanis Heritage, providing competency training in photography, videography and managing social media content to maximize the promotion of natural and cultural tourism of Pemanis Heritage. The outputs of this activity are mandatory outputs in the form of scientific articles published in national journals or articles on proceedings of national seminars, activity videos, articles on print/digital mass media, as well as increasing the empowerment of partners in Pemanis Heritage.
\end{abstract}

Keywords: social media, photography, videography, pemanis.

\section{PENDAHULUAN}

Pemanis Heritage adalah bagian dari kelompok wisata Desa Wisata Budaya Biaung yang terletak di Kecamatan Penebel, Kabupaten Tabanan, Provinsi Bali. Desa Biaung terdiri atas Desa Adat Biaung, Desa Adat Pumahan, Desa Adat Cacab Jangkahan, dan Desa
Adat Pemanis. Desa Adat Pemanis terdiri dari dua banjar dinas, yakni Banjar Dinas Pemanis Kelod dan Banjar Dinas Pemanis Kaja. Secara geografis, Desa Adat Pemanis terletak di bagian timur laut Kota Tabanan. Konsep Desa Wisata Budaya Biaung mulai dikembangkan sejak tahun 2006. Konsep Desa Wisata 
Budaya Biaung terdiri dari beberapa kelompok sadar wisata (POKDARWIS) yang berada di masing-masing desa adat di wilayah Desa Biaung.

POKDARWIS Desa Adat Pemanis yang selanjutnya disebut sebagai Pemanis Heritage pengelolaannya dilakukan secara mandiri oleh Desa Adat Pemanis dengan membentuk pengelola Pemanis Heritage. Kegiatannya melibatkan seluruh elemen masyarakat Desa Adat Pemanis, salah satunya Sekaa Teruna atau organsasi pemuda pemudi desa adat.

Pemanis Heritage mengedepankan wisata alam dan budaya. Hal ini sesuai dengan potensi Desa Adat Pemanis yang masih alami. Banyak wilayah Desa Pemanis yang ditumbuhi pepohonan sehingga tampak seperti hutan yang menghijau. Pemandangan alam ini ditambah dengan hamparan sawah menambah keindahan Desa Adat Pemanis. Wisata alam ditawarkan di Pemanis Heritage dengan kegiatan berjalan-jalan berkeliling desa, trekking melewati hutan dan sawah, serta kegiatan lain yang bertujuan untuk membawa wisatawan menikmati keindahan alam Desa Adat Pemanis.

Selain wisata alam, Pemanis Heritage juga mengembangkan wisata budaya. Desa Adat Pemanis memiliki beberapa peninggalan sejarah berupa pura dengan bangunan kuno yang masih berbentuk menhir dan punden berundak. Salah satu pura yang ada di Desa Adat Pemanis adalah Pura Batur Sri Murti yang sudah tercatat sebagai cagar budaya nasional yang dilindungi oleh negara. Bangunan pura seperti yang ada di Desa Adat Pemanis sudah jarang ditemui di Bali akibat pesatnya pembangunan. Kebanyakan pura di Bali saat ini sudah beralih pada bentuk bangunan dan arsitektur yang lebih modern, sehingga keberadaan bangunan menhir dan punden berundak di Desa Adat Pemanis bisa menjadi daya tarik budaya yang potensial dari Pemanis Heritage.

Konsep wisata Pemanis Heritage tidak hanya menjual hiburan, tetapi juga menekankan pada pelestarian budaya. Karenanya konsep-konsep atraksi wisata Pemanis Heritage dibuat sejalan dengan kehidupan masyarakat Desa Adat Pemanis. Mata pencaharian utama penduduk Desa Adat Pemanis didominasi oleh kegiatan agraris. Pertanian merupakan sektor utama yang menggerakkan ekonomi Desa Adat Pemanis. Sistem pertanian yang dilakukan di Desa Adat Pemanis hingga saat ini masih mengedepankan sistem tradisional seperti Subak. Kemampuan masyarakat mempertahankan tradisionalitas di tengah pesatnya kemajuan industri pertanian menjadi hal yang istimewa untuk diangkat sebagai potensi wisata Pemanis Heritage.

Berangkat dari kehidupan masyarakat agraris, maka diadakan atraksi metekap/ membajak sawah secara tradisional dengan menggunakan sapi Bali. Selain itu diadakan kegiatan workshop mengayam daun kelapa menjadi berbagai jenis kerajinan seperti topi hingga tas. Pemanis Heritage juga berusaha mengangkat potensi kuliner lokal yang diolah dari hasil-hasil pertanian di Desa Adat Pemanis seperti laklak biyu, suweg, karud, srebet, urab jlengut, ares, lempog, rujak kuud, sambel pangi, sambel nyuh, sambel kecicang, anyang, lawar klungah, palem yuyu, entil, dan tentu saja nasi beras hitam maupun merah yang menjadi komoditas utama persawahan di Desa Adat Pemanis. Kuliner-kuliner tersebut di atas merupakan kuliner tradisional Bali yang susah ditemukan untuk dinikmati karena belum tersentuh modifikasi komersial.

Segala potensi Desa Adat Pemanis di atas menjadikan Pemanis Heritage potensial sebagai daerah tujuan wisata baru di Bali. Sejak awal pengembangannya, Pemanis Heritage harus bersaing dengan daerah-daerah lain di Bali yang sudah lebih dahulu dikenal sebagai objek wisata. Lokasi Pemanis Heritage yang berada di Kabupaten Tabanan juga belum dikenal luas sebagai daerah tujuan wisata di Bali. Potensi Pemanis Heritage untuk berkembang sebagai daerah tujuan wisata sebenarnya sangat besar. Hanya saja diperlukan adanya strategi promosi yang tepat agar Pemanis Heritage bisa berkembang menjadi daerah tujuan wisata alam dan budaya di Bali.

Masalah mendasar yang dialami POKDARWIS Pemanis Heritage dalam pengembangan wisata adalah belum adanya logo yang bisa menjadi identitas dari Pemanis Heritage. Sign board, info grafis, media promosi dan sign system yang bisa mendukung pengembangan Pemanis Heritage juga belum layak. Pengemasan identitas dan media pendukungnya diperlukan untuk bisa membangun Pemanis Heritage sebagai daerah yang layak dikunjungi untuk wisata alam dan budaya.

Masalah lain yang ada di Pemanis Heritage adalah kurang maksimalnya promosi yang dilakukan. Berbagai upaya telah dilakukan untuk mempromosikan Pemanis Heritage sebagai daerah tujuan wisata termasuk promosi digital. Hingga saat ini Pemanis Heritage telah tampil dalam website Wisata Budaya Biaung, yakni di www.wisatabudayabiaung.com. Pemanis Heritage juga memiliki akun sosial media yakni facebook Pemanis Heritage dan instagram 
@ pemanisheritage. Sayangnya pengelolaan kedua akun media sosial ini belum maksimal, sehingga promosi Pemanis Heritage sebagai daerah tujuan wisata belum mencakup masyarakat luas sehingga tingkat kunjungan wisata di Pemanis Heritage masih rendah. Situasi pandemi covid-19 yang sedang melanda Bali dan dunia saat ini semakin menurunkan tingkat kunjungan wisatawan di Pemanis Heritage. Karenanya diperlukan adanya strategi baru untuk menambah kunjungan wisata di Pemanis Heritage, terutama untuk membantu masyarakat mendapatkan penghasilan tambahan dari wisata selain dari bidang agraris.

Saat ini media sosial telah menjelma menjadi media promosi yang paling efektif. Terbukti dengan banyaknya daerah yang sebelumnya bukan daerah wisata, menjelma menjadi daerah wisata populer karena viral di media sosial. Setiap daerah yang viral tersebut biasanya mempunyai keunikan atau potensi tertentu yang dikemas secara menarik dalam konten media sosial berupa foto dan/atau video sehingga menarik minat wisatawan untuk berkunjung. Pemanis Heritage memiliki banyak potensi sesuai yang telah dijabarkan sebelumnya, dari keindahan alam hingga budaya dan kulinernya. Dengan potensi yang sedemikian banyak perlu adanya promosi media sosial yang baik dengan membuat konten-konten menarik berupa foto, video, maupun info-info unik yang bisa menarik minat wisatawan untuk berkunjung. Pengelola Pemanis Heritage juga belum memiliki strategi promosi di media sosial terutama mengenai pengetahuan dasar digital marketing sehingga promosi Pemanis Heritage di media sosial tidak berjalan dengan maksimal.

Masalah lain yang perlu diperhatikan di Pemanis Heritage adalah pengemasan foto dan video yang akan ditampilkan di media sosial Pemanis Heritage dengan lebih profesional. Perlu adanya pengetahuan mengenai teknik-teknik fotografi dan teknik-teknik videografi yang baik agar bisa menampilkan foto dan video untuk membentuk image Pemanis Heritage sebagai desa wisata alam dan budaya. Foto dan video yang sudah di unggah di akun media sosial Pemanis Heritage selama ini belum mampu menampilkan keindahan alam dan budaya Desa Adat Pemanis secara maksimal, sehingga kurang menarik minat wisatawan untuk berkunjung ke Pemanis Heritage. Permasalahan ini terjadi akibat belum adanya sumber daya manusia di Desa Adat Pemanis yang memiliki pengetahuan dan keahlian fotografi dan videografi yang mumpuni, sehingga konten foto dan video di media sosial Pemanis Heritage belum dikemas dengan baik.

\section{KAJIAN TEORI}

Budaya Visual (visual culture) merujuk pada kondisi dimana visual menjadi bagian dari kehidupan sosial (Ida, 2014: 27). Modernitas saat ini berpusat pada aspek visual. Visual menjadi hal utama pada postmodernitas, seperti yang tampak pada penggunaan sosial media saat ini. Dalam pengembangan konten media sosial sebagai media promosi, perlu adanya pelatihan penguatan kompetensi fotografi, videografi dan tata kelola media sosial.

Penciptaan karya fotografi bisa didasarkan untuk berbagai kepentingan dengan menyebutnya sebagai suatu medium 'penyampai pesan' (message carier) bagi tujuan tertentu. Karya fotografi disamping kediriannya yang mandiri juga dimanfaatkan bagi memenuhi suatu fungsi tertentu (Soedjono, 2006: 27), termasuk fungsinya sebagai konten visual pada media sosial.

Videografi merupakan sebuah media yang dapat dipergunakan untuk merekam suatu kejadian tertentu yang dirangkum ke dalam suatu gambar (video) dan suara (audio). Videografi digunakan untuk sebuah kajian maupun dibuat untuk kemudian dilihat di kemudian hari. Penggunaan videografi disesuaikan dengan kepentingan atau keperluan masing-masing. Pada budaya visual, videografi memegang peranan penting terutama dalam media sosial.

Publik sudah sangat tergantung dengan gadget atau smartphone akibat fleksibilitas dan berbgai kemudahan yang ditawarkan. Di era ekonomi digital, pendekatan pemasaran dilakukan dengan mengkombinasikan interaksi online dan interaksi offline antara perusahaan dengan pelanggan yang tujuan utamanya memenangkan, advokasi konsumen (Asiani, 2019: 58). Hal yang sama coba dilakukan di Pemanis Heritage dengan melaksanakan pelatihan Tata Kelola Konten Media Sosial, dimana pelatihan dipusatkan pada pengelolaan akun Instagram @pemanis_heritage sebagai media promosi. Instagram dipilih sebagai media promosi digital karena Instagram merupakan media sosial yang berfokus pada konten foto dan video.

\section{METODE PENELITIAN}

\section{Eksperimen}

Kegiatan Pengabdian Kemitraan Masyarakat Penguatan Penguasaan Travel Fotografi, Videografi dan Tata Kelola Media Promosi Sosial Media Pada POKDARWIS Pemanis Heritage, Desa Wisata Biaung, Tabanan, Bali merujuk pada permasalahan mendasar yang dialami POKDARWIS Pemanis Heritage. Adapun metode pelaksanaan yang akan dilaksanakan 


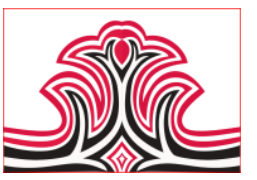

dalam program ini telah disepakati bersama POKDARWIS Pemanis Heritage selaku mitra: a). Membantu membentuk identitas dari POKDARWIS Pemanis Heritage sebagai daerah tujuan wisata dan budaya dengan membuat logo, info grafis, media promosi dan sign sistem., b). Mengembangkan strategi promosi POKDARWIS Pemanis Heritage dengan memberi pelatihan pengetahuan dasar tata kelola konten media sosial kepada pengelola POKDARWIS Pemanis Heritage dan anggota Sekaa Teruna Desa Adat Pemanis., c). Memberi pelatihan travel fotografi dan videografi bagi Pengelola POKDARWIS Pemanis Heritage dan anggota Sekaa Teruna Desa Adat Pemanis. Travel fotografi dan videografi merupakan salah bahan yang bisa menjadi konten media promosi di media sosial Pemanis Heritage., d). Memotivasi pengembangan Pemanis Heritage sebagai daerah tujuan wisata alam dan budaya dengan tetap mempertahankan kelestarian alam dan budaya di Desa Adat Pemanis.

\section{HASIL DAN PEMBAHASA}

\section{Hasil}

Keluaran yang telah dicapai selama masa pengabdian masyarakat hingga bulan Agustus 2021 adalah: a). Data potensi desa Pemanis, b). Pelatihan fotografi, c). Pelatihan videografi, d). Tata kelola konten media sosial, dan e). Logo Pemanis Heritage.

\section{Pembahasan}

\section{1). Data Potensi Desa Pemanis}

Sebelum pelaksanaan kegian PKM ini, belum pernah ada yang melakukan pendataan potensi desa yang dimiliki oleh Desa Pemanis. Setelah beberapa kali melakukan kunjungan ke Desa Pemanis, diperoleh beberapa potensi yang bisa dikembangkan menjadi daya tarik wisata alam dan budaya, diantaranya:

\section{(1). Bentang Alam Pemanis}

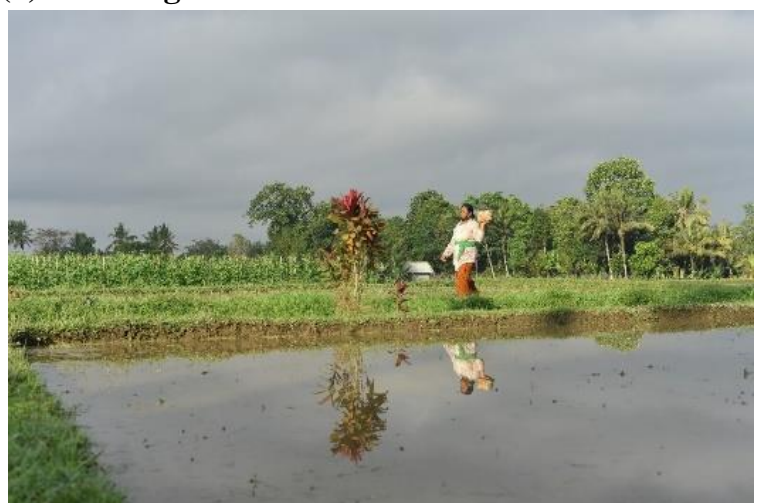

Gambar 1. Sawah di Desa Pemanis yang Dekat dengan Kehidupan Masyarakat

Pemanis yang terletak di tengah-tengah persawahan menjadikan bentang alamnya unik. Di sepanjang
Gorga : Jurnal Seni Rupa

Volume 10 Nomor 02 Juli-Desember 2021 p-ISSN: 2301-5942 | e-ISSN: 2580-2380

wiilayah desa, terdapat banyak sawah dan kebun yang membentang luas dengan beberapa gunung di utara desa, tanpa ada bangunan yang menjadi penghalang pemandangan. Pemandangan seperti ini sangat jarang bisa ditemui di Bali saat ini mengingat pesatnya pembangunan di banyak wilayah akibat kemajuan pariwisata. Pemanis seolah tidak tergerus oleh jaman dan masih tampak alami dengan bentang sawah dan kebunnya.

\section{(2). Potensi Agraris}

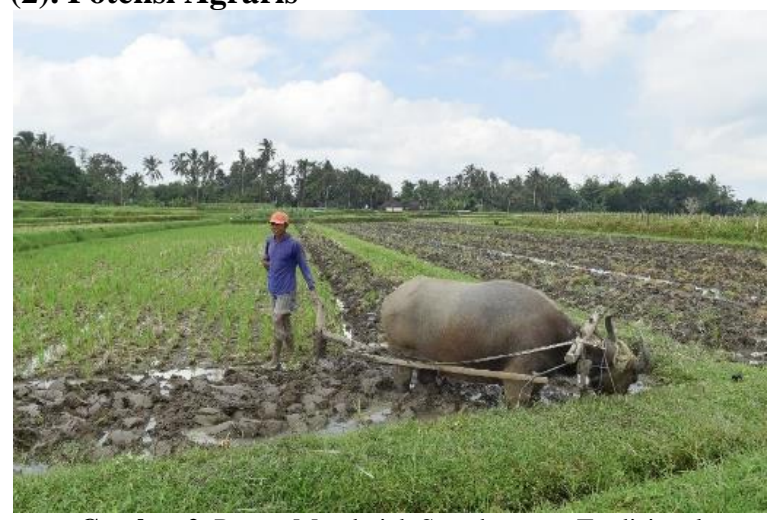

Gambar 2. Proses Membajak Sawah secara Tradisional

Desa Pemanis berpotensi menjadi daerah wisata agraris. Sistem pertanian yang masih menggunakan subak sebagai sistem irigasinya memanfaatkan sungaisungai jernih yang mengalir di sekitar wilayah desa. Sistem pertanian di Desa Pemanis juga masih menggunakan cara-cara tradisional, seperti membajak sawah dengan menggunakan bantuan sapi. Hal-hal seperti ini sudah jarang terlihat di daerah lain, dimana sistem pertaniannya sudah lebih modern. Hasil alam dari Pemanis adalah padi, rimpang seperti jahe, kunyit, dan sayur-sayuran. Dengan kata lain Desa Pemanis memiliki sumber pangannya sendiri. Hal ini menjadikan Desa Pemanis sangat potensial sebagai daerah tujuan wisata agraris.

Selain itu, di Desa Pemanis juga terdapat tanaman pangan langka yang mulai sulit didapatkan di daerah lain. Masyarakat Pemanis masih melestarikan beberapa jenis tanaman seperti umbi biaung yang merupakan tanaman sejenis umbi-umbian yang dapat dikonsumsi. Gungung atau rasberi lair juga masih banyak yang tumbuh di areal persawahan Desa Pemanis. Kedua tanaman langka ini bisa menjadi daya tarik tersendiri bagi wisatawan yang berkunjung ke Desa Pemanis.

\section{(3). Potensi Kuliner}

Desa Pemanis memiliki beberapa jenis kuliner khas yang tidak bisa ditemukan di daerah lain. Menikmati kuliner di pemanis bisa membawa pengunjung ke masa lalu. Pedagang-pedagang di Pemanis masih berjualan 


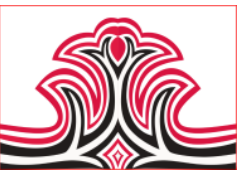

dengan meja-meja kecil, atau di banguanan umum milik desa seperti balai bengong. Mereka menjajakan makanan dan minuman yang diproduksi sendiri. Cara berjualannya pun unik, dengan sistem kepercayaan. Masyarakat yang belum memiliki uang bisa tetap berbelanja dengan berutang, lalu membayarkannya pada saat ada upacara besar di pura. Saat itu para pedagang akan berkumpul berjualan di area pura dan masyarakat pasti akan datang bersembahyang ke pura. Maka hari itu penjual dan pembeli pasti bertemu kembali, memungkinkan terjadinya proses pembayaran utang.

Kuliner yang ada di Pemanis adalah kulek. Bila di daerah Bali lainnya kulek adalah kolak, yakni potongan pisang atau ubi yang direbus bersama gula merah dan disajikan dengan santan kelapa, di Desa Pemanis "kolek" adalah minuman dingin yang disajikan dengan tape ketan, cendol dari tepung beras, gula merah dan santan.

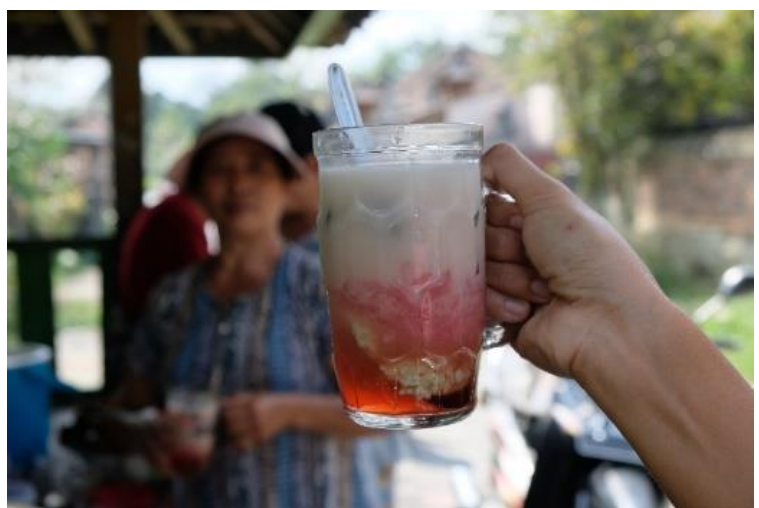

Gambar 3. Es Kulek, Kuliner Khas Desa Pemanis

Selain kulek, bubuh atau bubur juga menjadi panganan khas Desa Pemanis. Bubur beras disajikan bersama sayuran hasil kebun, dengan disiram kuah berbumbu khas Pemanis.

Ada pula Anyang, sajian mirip lawar yang terbuat dari daging ayam. Biasanya anyang hanya dibuat di harihari tertentu, saat ada hari besar/ upacara untuk dimakan bersama keluarga.

\section{(4). Potensi Budaya}

Desa Pemanis merupakan sebuah desa tua yang memiliki banyak budaya lokal dan situs. Bangunanbangunan Pura yang ada di Desa Pemanis masih asli meninggalkan jejak kebudayaan lama. Masyarakatnya pun masih menjalankan tradisi seperti cara bertani, sistem kemasyarakatan, bentuk religi, hingga hiburan yang sarat dengan kesenian seperti mekekawin, tari dan tabuh. Salah satu pelestariannya adalah lewat Sanggar Teba Kangin Pemanis, yang merupakan bagian dari Pemanis Heritage. Potensi budaya ini
Gorga : Jurnal Seni Rupa

Volume 10 Nomor 02 Juli-Desember 2021 p-ISSN: 2301-5942 | e-ISSN: 2580-2380

sangat menarik untuk diangkat dalam foto dan video sebagai konten promosi di media sosial. Dengan pengemasan yang baik, Pemanis akan menjadi dikenal sebagai daerah wisata budaya.

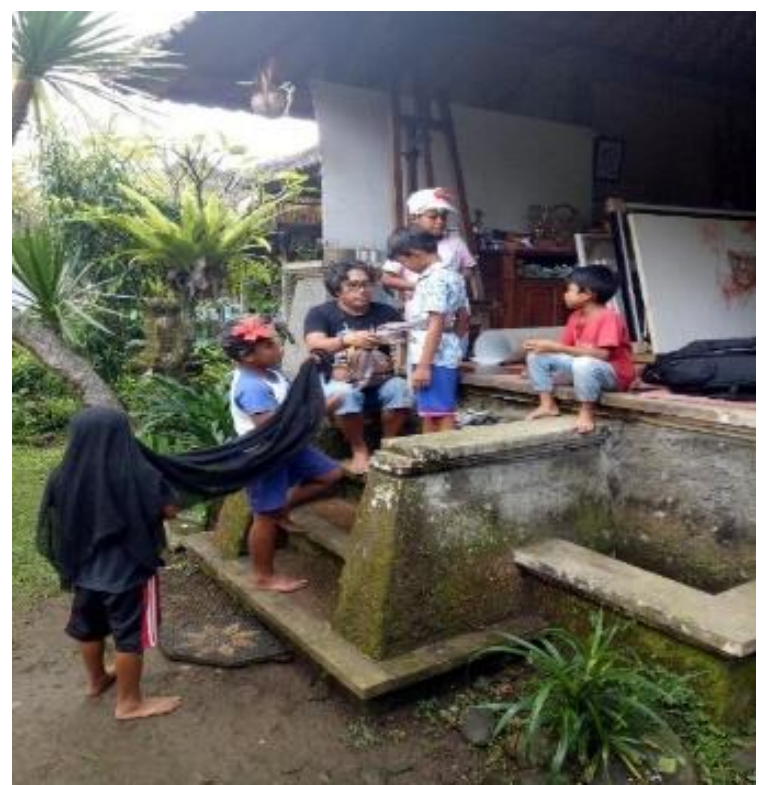

Gambar 4. Latihan Menari Barong di Sanggar Teba Kangin Pemanis

\section{2). Pelatihan Fotografi}

Pelatihan Fotografi yang dilakukan di Pemanis menyasar pengelola POKDARWIS Pemanis Heritage dan Sekaa Teruna Teruni Swastika Teruna Pemanis. Pelatihan fotografi dilakukan dengan pendekatan yang berbeda dengan proses pembelajaran di kampus, mengingat keterbatasan kemampuan dan pengetahuan yang dimiliki oleh sasaran pelatihan

Pelatihan Fotografi dilakuan sebanyak 3 kali yaitu pada tanggal 11 dan 22 Agustus 2021 serta pada tanggal 5 Agustus 2021. Pelatihan difokuskan pada teknik-teknik dasar fotografi seperti pengenalan cahaya dan sifat cahaya, komposisi, dan tata cahaya. Pelatihan dilakukan secara terpisah dalam 3 kegiatan dengan melibatkan maksimal 10 orang termasuk pelatih karena adanya PPKM Level 4 yang diterapkan di seluruh wilayah Bali, sehingga tidak boleh ada kerumunan massa atau pun kegiatan yang berpotensi menyebabkan penyebaran virus Covid-19. Pelatihan fotografi pun dilakukan dengan selalu memperhatikan protokol Kesehatan yakni mencuci tangan, menjaga jarak dan memakai masker.

Proses pelatihan fotografi dilakukan dengan memberikan materi mengenai dasar-dasar fotografi terlebih dahulu dengan cara mengobrol dengan peserta pelatihan, berdiskusi ringan, sambil memperlihatkan contoh-contoh karya foto yang dimaksud. Kemudian 


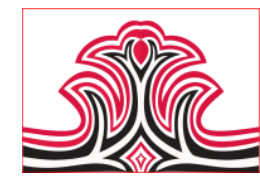

pelatihan dilanjutkan dengan membuat peserta mencoba menghasilkan sebuah karya foto dengan $\mathrm{Hp}$ yang mereka miliki. Setelahnya peserta diperbolehkan mencoba memotret dengan menggunakan kamera profesional. Objek yang difoto oleh peserta adalah objek-objek yang ada di sekitar wilayah Desa Pemanis.

Rata-rata peserta menikmati proses pelatihan ini karena mereka melihat tempat-tempat di Desa Pemanis yang tadinya tampak biasa saja di mata mereka menjadi sangat menarik di mata kamera.

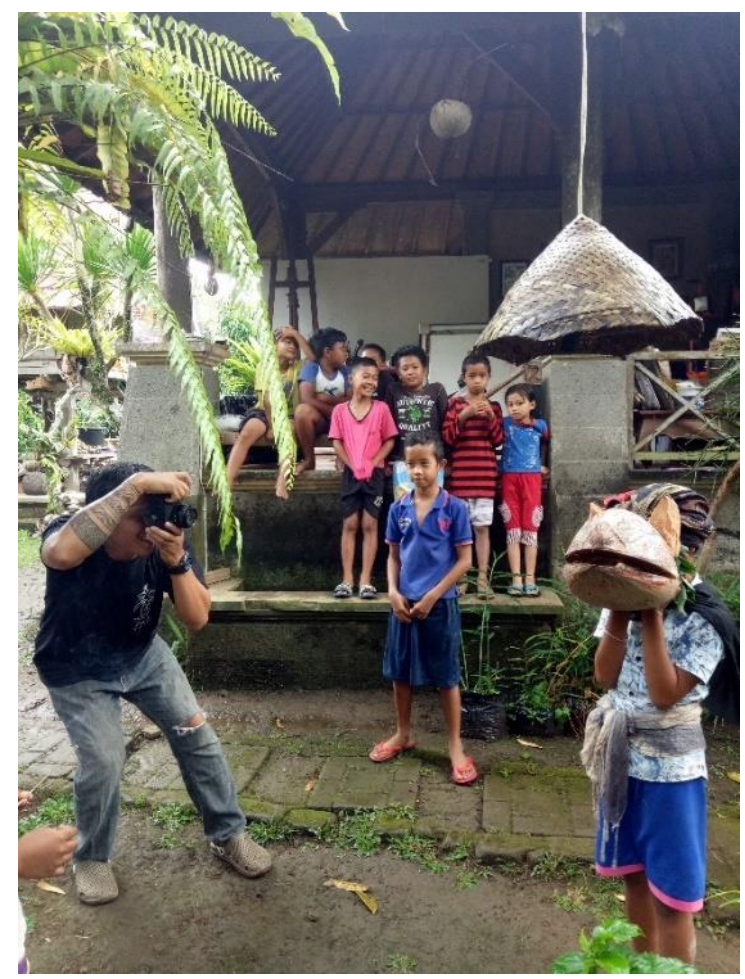

Gambar 5. Peneliti Memberikan Contoh Proses Memotret
Gorga : Jurnal Seni Rupa

Volume 10 Nomor 02 Juli-Desember 2021 p-ISSN: 2301-5942 |e-ISSN: 2580-2380

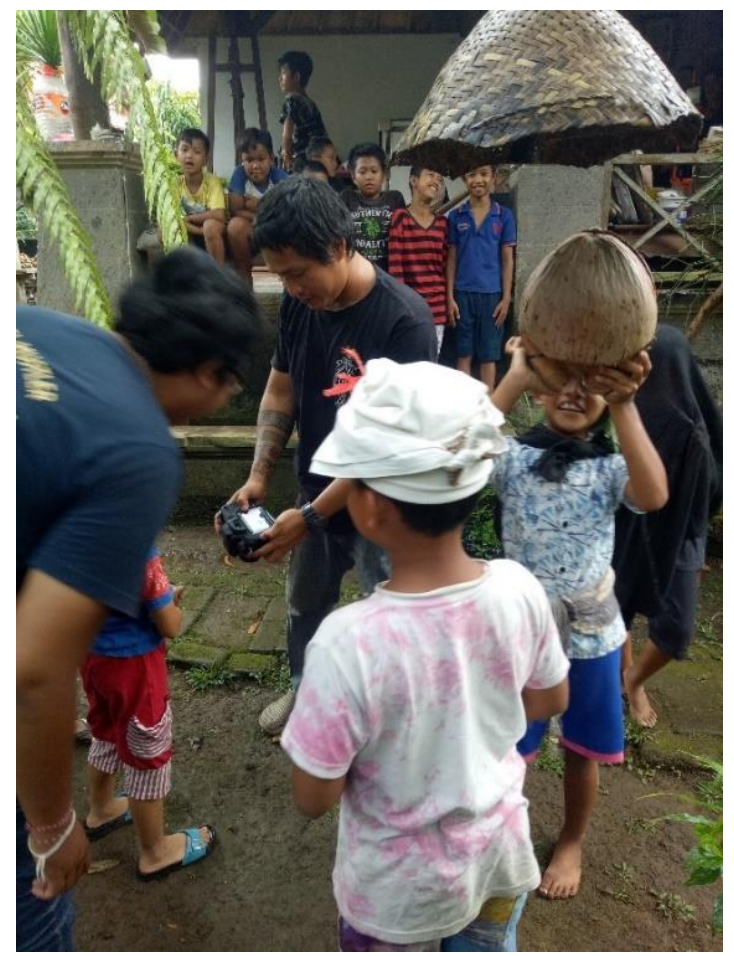

Gambar 6. Peserta Pelatihan Antusias Melihat Hasil Foto

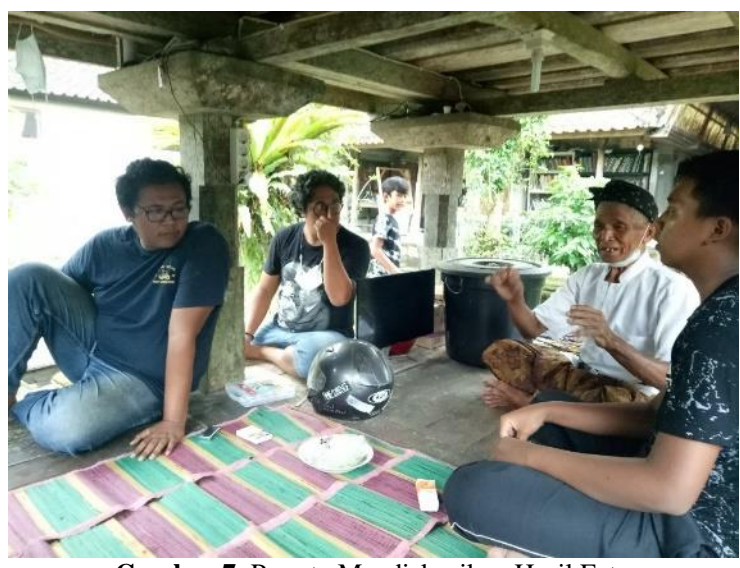

Gambar 7. Peserta Mendiskusikan Hasil Foto

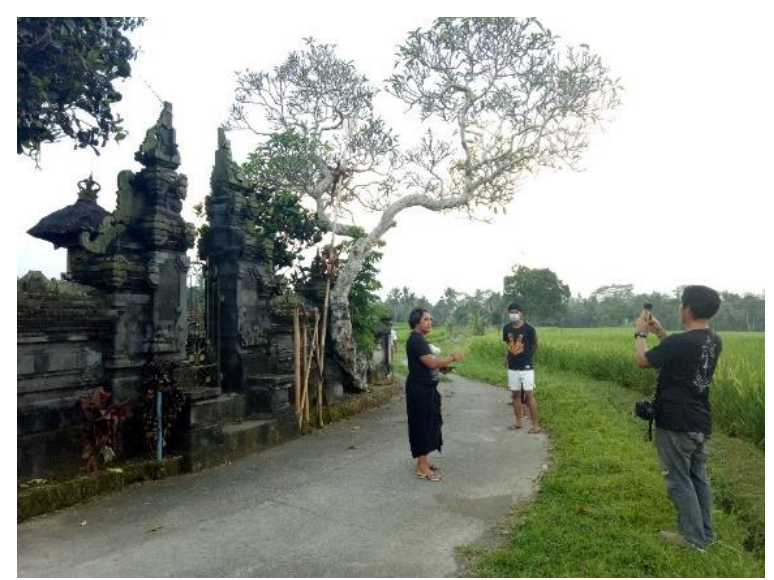

Gambar 8. Peserta Pelatihan Fotografi Mencoba Memotret

\section{3). Pelatihan Videografi}

Proses pelatihan videografi yang dilakukan di Desa Pemanis secara garis besar mirip dengan proses pelatihan fotografi. Pelatihan videografi dilakukan di 


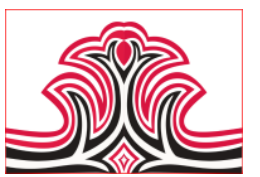

hari yang sama pada saat pelatihan fotografi untuk memaksimalkan penggunaan alat. Setelah mendapat materi tentang fotografi, peserta pelatihan dapat langsung mempraktekan mengambil video/gambar bergerak. Pada dasarnya videografi berasal dari rumpun ilmu yang sama dengan fotografi. Oleh karena itu pilihan untuk mengadakan kedua pelatihan ini secara bersama dinilai efektif, terlebih di masa pelaksanaan PPKM Level 4 di Bali yang membatasi ruang gerak.

Proses pelatihan videografi dilakukan dengan mengajak peserta pelatihan mengambil video di wilayah sekitar Desa Pemanis dengan terlebih dahulu memberikan materi berupa pembekalan teori dasar videografi.

Para peserta tampak sangat bersemangat mempelajari teori videografi dan mempraktekkannya dengan menggunakan kamera Hp masing-masing. Selanjutnya peserta diajak mencoba menggunakan kamera digital dalam membuat video.

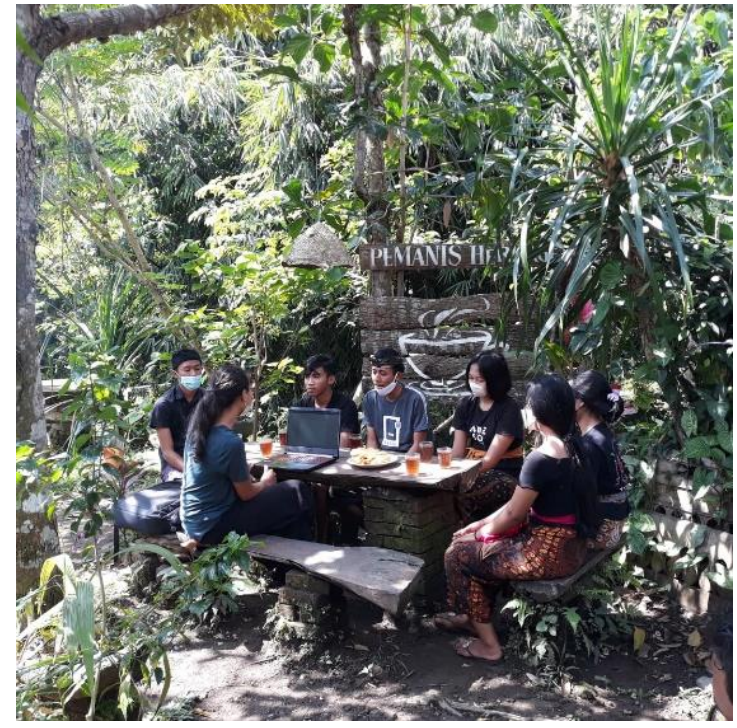

Gambar 9. Diskusi tentang Video bersama Peserta Pelatihan

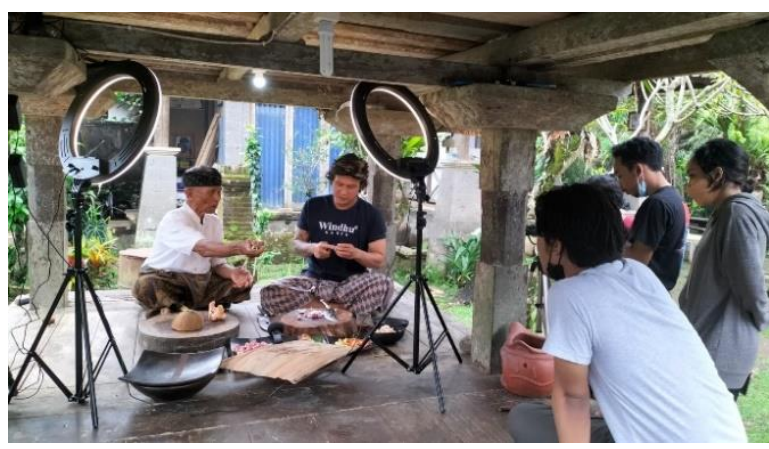

Gambar 10. Peserta Pelatihan Praktek Videografi
Gorga : Jurnal Seni Rupa

Volume 10 Nomor 02 Juli-Desember 2021 p-ISSN: 2301-5942 | e-ISSN: 2580-2380

\section{4). Tata Kelola Konten Media Sosial}

Selama melakukan kegiatan PKM di Desa Pemanis, selain melaksanakan kegiatan pelatihan, peneliti juga melakukan kegiatan pengambilan gambar berupa foto maupun video yang selanjutnya akan dipergunakan sebagai bahan untuk mengelola media sosial Pemanis Heritage. Peneliti sudah membuat sebuah akun Instagram baru untuk branding POKDARWIS Pemanis Heritage sebagai desa wisata alam dan budaya. Akun Instagram tersebut adalah @ pemanis_heritage.

Akun inilah yang nantinya akan diisi dengan kontenkonten media sosial yang sudah dikumpulkan selama kegiatan PKM berlangsung, baik foto maupun video. Akun media sosial ini juga akan menjadi bahan praktek bagi peserta pelatihan untuk belajar memaksimalkan manfaat sosial media sebagai media promosi desnya. Akun@pemanis_heritage selanjutnya akan dipergunakan dalam pelatihan pengelolaan media sosial Pemanis Heritage.

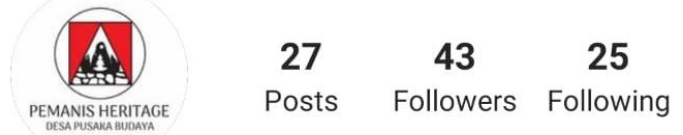

Pemanis Heritage

Desa Pusaka Budaya

Desa Pemanis, Biaung, Tabanan, Bali

See translation

Gambar 11. Akun Instagram @pemanis_heritage

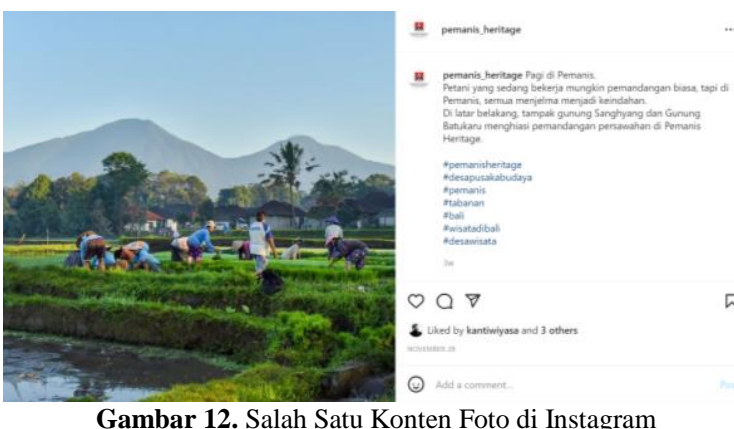

\section{5). Logo Pemanis Heritage}

Desain Logo Pemanis Heritage dibuat berdasarkan arahan dan konsep yang diinginkan oleh Pengelola POKDARWIS Pemanis Heritage, dengan mempertimbangkan unsur-unsur desain di dalamnya. Pembuatan desain logo POKDARWIS Pemanis Heritage diserahkan kepada seorang Desainer Komunikasi Visual yang sebelumnya telah melakukan komunikasi dengan peneliti dan Bakti Wiyasa sebagai perwakilan dari POKDARWIS Pemanis Heritage. Berdasarkan diskusi yang telah dilakukan, konsep 


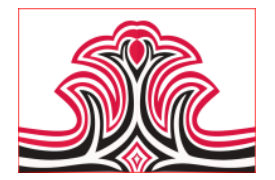

Logo Pemanis Heritage berasal dari unsur alam dan budaya di Desa Pemanis, di antaranya.

\section{(1). Bebaturan}

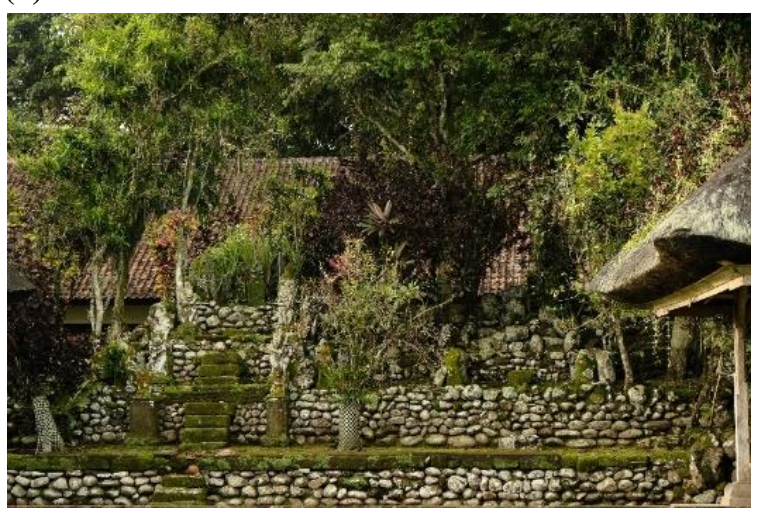

Gambar 13. Bebaturan di Pura Batur Sari

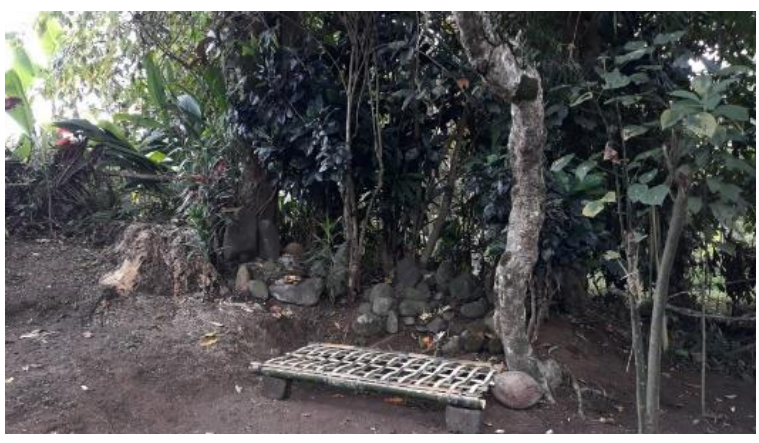

Gambar 14. Bebaturan di Sekitar Desa Pemanis

\section{(2). Budaya Religi}

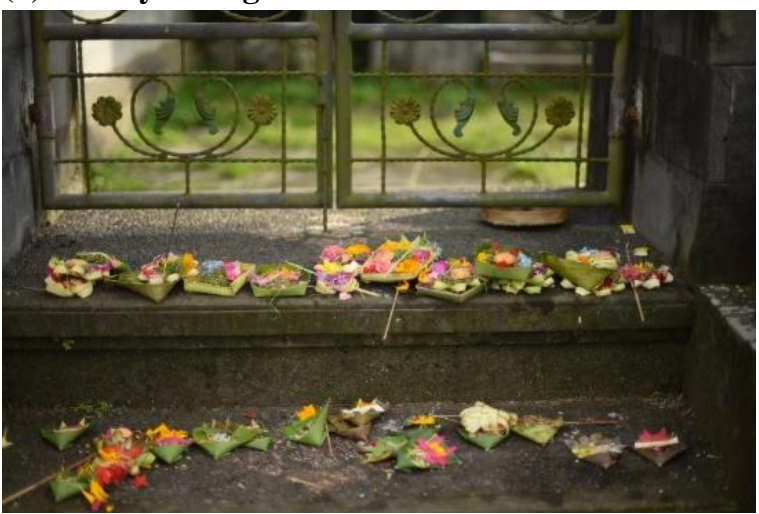

Gambar 15. Sesaji / Canang di Depan sebuah Pura di Desa Pemanis

Berikut rancangan desain logo Pemanis Heritage yang selanjutkan akan diterapkan dalam segala bentuk media promosi POKDARWIS Pemanis Heritage.
Gorga : Jurnal Seni Rupa

Volume 10 Nomor 02 Juli-Desember 2021 p-ISSN: 2301-5942 | e-ISSN: 2580-2380

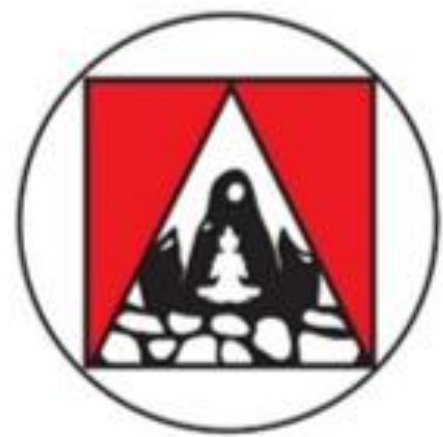

\section{PEMANIS HERITAGE DESA PUSAKA BUDAYA}

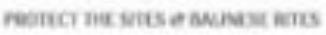

Gambar 16. Rancangan Desain Logo Pemanis Heritage

Peningkatan pada mitra dapat terlihat pada kemampuan mitra, yakni Anggota Pokdarwis Pemanis Heritage dalam kecakapan fotografi maupun videografi. Penambahkan kecakapan ini dapat terlihat dari perbedaan foto dan video yang diunggah di Instagram @pemanis_heritage terlihat jauh lebih baik kualitas videonya dibandingkan dengan akun sosial media yang sebelumnya dikelola oleh peserta, yakni akun @ pemanisheritage yang merupakan akun media sosial lama dari Pemanis Heritage yang saat ini sudah tidak dapat diakses karena permasalahan teknis.
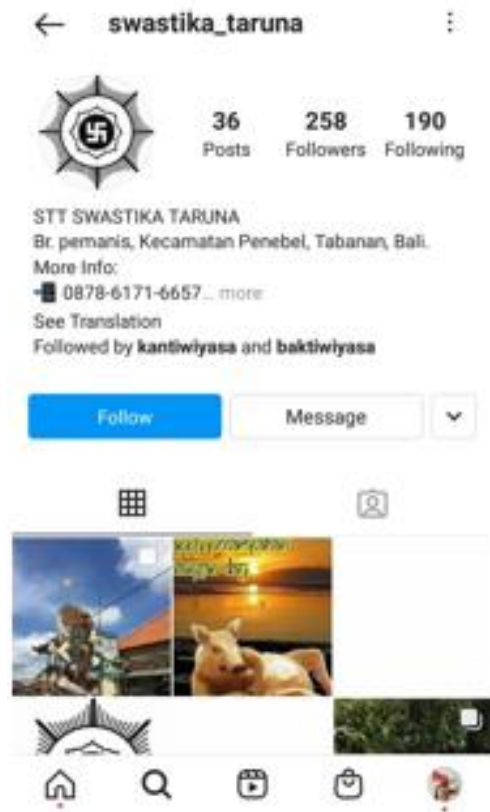

Gambar 17. Konten Akun Media Sosial @pemanis_heritage

Media sosial di atas merupakan akun media sosial dari Sekaa Teruna Teruni Swastika Taruna Desa Pemanis. Media sosial Instagram ini dikelola oleh peserta pelatihan PKM dari Sekaa Teruna. Pada foto di atas, 


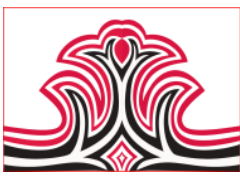

terlihat bahwa foto-foto yang diunggah di akun tersebut tidak mempertimbangkan nilai estetika maupun informasi yang ditampilkan oleh foto. Banyak gambar yang ditampilkan adalah gambar asal unggah, tanpa mempertimbangkan kualitas foto. Info grafis (foto di kanan) yang seharusnya veritkal ditampilkan secara horizontal dan tidak lengkap. Sosial media yang seharusnya bisa menjadi ajang promosi justru hanya berkembang sebagai media album foto dokumentasi semata.
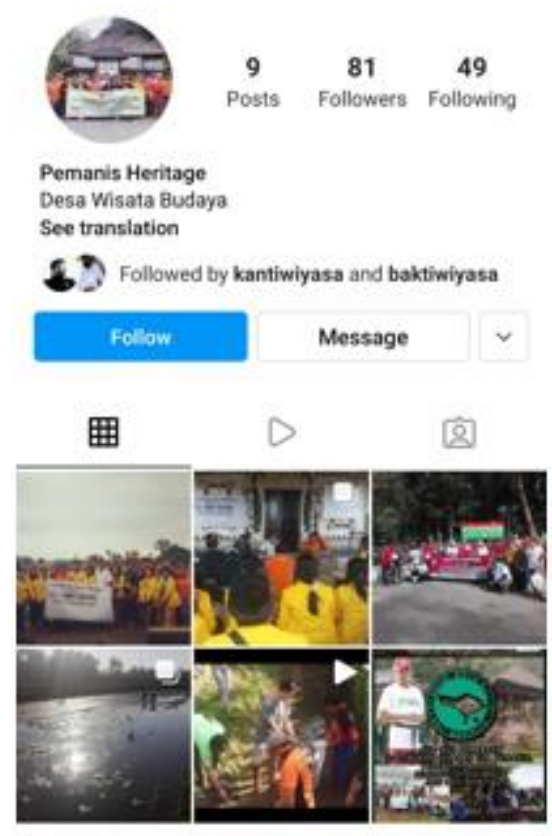

Gambar 18. Konten Akun Media Sosial Lama @ pemanisheritage

Pemanis Heritage sebenarnya sudah memiliki akun Instagram yakni @ pemanisheritage. Namun, selain pengelolaannya yang belum maksimal, akun ini sudah tidak aktif lagi. Pengelola akunnya pun sudah tidak dapat mengakses akun tersebut karena kehilangan kata kuncinya. Selain itu, pemilihan nama @ pemanisheritage menyulitkan orang untuk melafalkan dan mengingat nama akun tersebut karena tidak adanya tanda baca diantara kata Pemanis dan Heritage. Selain itu, foto dan video yang diunggah di sosial media@pemanisheritage belum terstruktur sehingga tidak mampu memberi kesan Pemanis sebagai daerah wisata alam dan budaya kepada khalayak. Atas pertimbangan ini, peneliti membuatkan akun baru sekaligus untuk rebranding sosial media @ pemanis_heritage. Konten foto dan video yang sudah diungah dan akan diunggah di akun @pemanis_heritage sebelumnya akan mengalami proses kurasi atau melalui proses tata kelola konten media sosial, sehingga dapat dipastikan konten sosial medianya akan sejalan dengan visi menjadikan Pemanis Heritage sebagai daerah wisata alam dan budaya.
Gorga : Jurnal Seni Rupa

Volume 10 Nomor 02 Juli-Desember 2021 p-ISSN: 2301-5942 | e-ISSN: 2580-2380

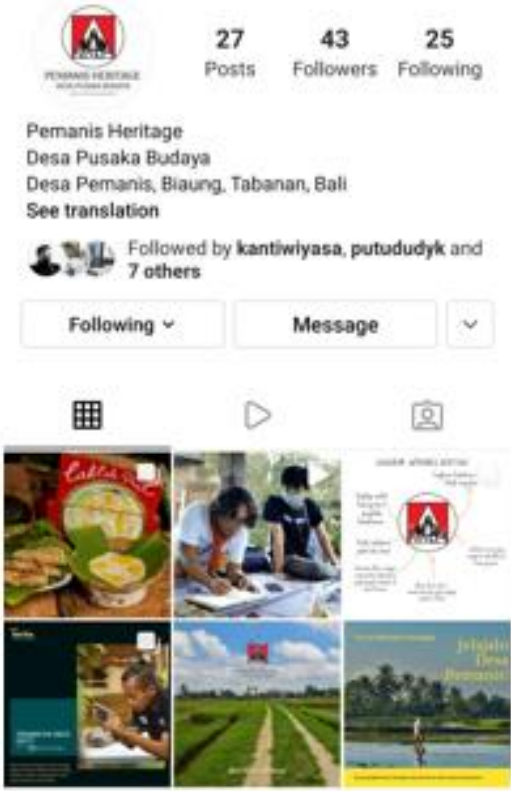

Gambar 19. Akun Baru @ pemanis_heritage

Pada akun baru@pemanis_heritage, bisa dilihat konten yang diuggah di sosial media tersebut langsung menuju pada wisata alam dan budaya. Bisa dilihat dari konten foto-foto sawah dan keberadaan situs bebaturan yang diunggah di akun tersebut. Selanjutnya, akun @ pemanis_heritage ini akan lebih dikembangkan lagi dalam tahapan selanjutnya, yakni proses pelatihan tata kelola konten media sosial.

Peningkatan pada mitra lainnya dapat dilihat dari contoh kecakapan hasil karya foto dan video yang dihasilkan oleh beberapa peserta pelatihan, sebelum dan sesudah pelatihan. Foto sebelum merupakan karya peserta yang sudah diunggah di akun @Swastika_Taruna atau akun lama @ pemanisheritage. Sedangkan foto sesudah pelatihan adalah foto-foto peserta yang lolos kurasi dan ditampilkan di akun baru @ pemanis_heritage berikut. Nama Peserta Pelatihan: Kanti Wiyasa. 


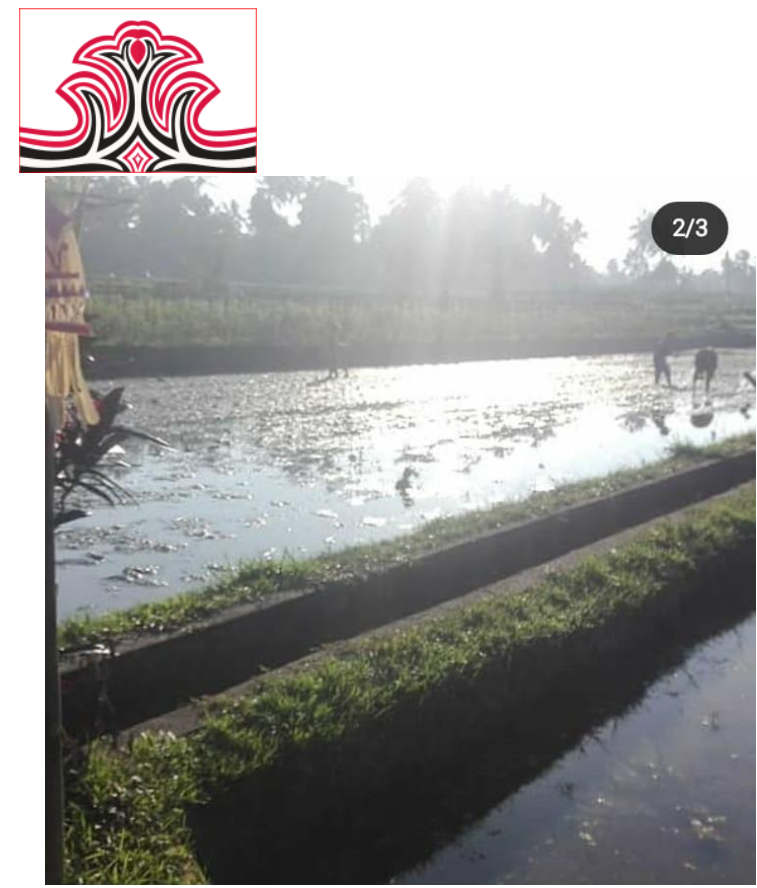

Gambar 20. Foto Sawah Terlihat Putih/ Over Exposure karena Saat Memotret Melawan Arah Datangnya Cahaya

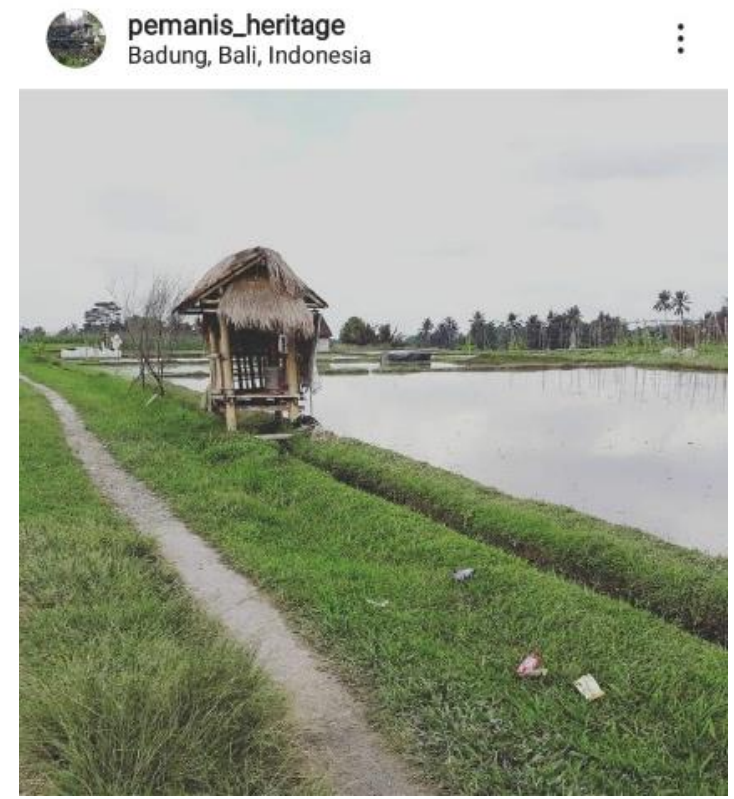

Gambar 21. Foto Sawah Terlihat Lebih Baik ketika Peserta sudah Memahami Komposisi dan Arah Datangnya Cahaya. Jalan setapak

Dipergunakan sebagai Leading Line yang Mengarahkan Mata Khalayak pada Gubuk Petani sebagai Fokus Utama.

Selain karya foto di atas, hasil yang diperoleh dari pelatihan ini adalah sebuah karya video yang berjudul "Anyang, Boga Amerta Pemanis". Karya video ini menggambarkan anyang, makanan khas desa pemanis dari bahan, cara pembuatan hingga hasil akhirnya. Dalam proses produksi karya ini, dilakukan kolaborasi antara tim pelaksana PKM yaitu dosen, mahasiswa dan masyarakat Desa Pemanis. Seorang tokoh Pemanis Heritage yakni I Ketut Muka atau yang akrab dipanggil Kak Rika, menjadi tokoh utama dalam video ini. Kak Rika berperan sebagai pembuat anyang sekaligus narasumber utama dalam video ini.
Gorga : Jurnal Seni Rupa

Volume 10 Nomor 02 Juli-Desember 2021

p-ISSN: 2301-5942 | e-ISSN: 2580-2380
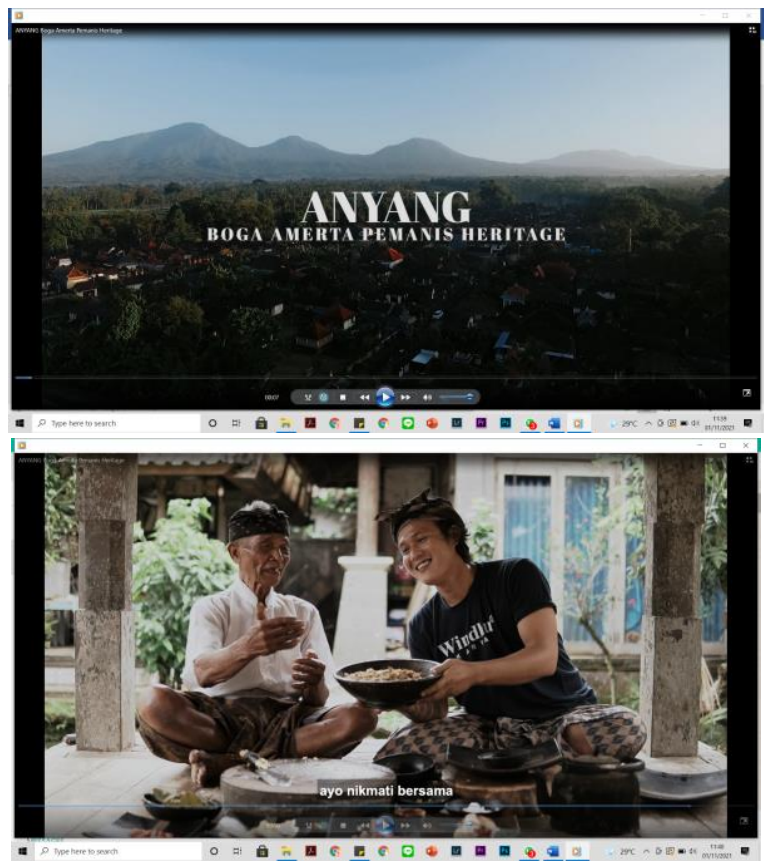

Gambar 22. Video Anyang, Boga Amerta Pemanis sebagai Luaran Pelatihan Videografi

\section{KESIMPULAN DAN SARAN}

\section{Kesimpulan}

Pemanis Heritage adalah bagian dari kelompok wisata Desa Wisata Budaya Biaung yang terletak di Kecamatan Penebel, Kabupaten Tabanan, Provinsi Bali. Konsep Desa Wisata Budaya Biaung mulai dikembangkan sejak tahun 2006. Konsep Desa Wisata Budaya Biaung terdiri dari beberapa kelompok sadar wisata (POKDARWIS) yang berada di masing-masing desa adat di wilayah Desa Biaung. POKDARWIS Desa Adat Pemanis yang selanjutnya disebut sebagai Pemanis Heritage pengelolaannya dilakukan secara mandiri oleh Desa Adat Pemanis dengan membentuk pengelola Pemanis Heritage dan kegiatannya melibatkan seluruh elemen masyarakat Desa Adat Pemanis salah satunya Sekaa Teruna atau organsasi pemuda pemudi desa adat.

Pemanis Heritage mengedepankan wisata alam dan budaya. Hal ini sesuai dengan potensi Desa Adat Pemanis yang masih alami. Data Potensi Desa Pemanis Sebelum pelaksanaan kegitan PKM ini, belum pernah ada yang melakukan pendataan potensi desa yang dimiliki oleh Desa Pemanis. Setelah beberapa kali melakukan kunjungan ke Desa Pemanis, diperoleh beberapa potensi yang bisa dikembangkan menjadi daya tarik wisata alam dan budaya, diantaranya bentang alam, potensi wisata agraris, potensi kuliner, dan potensi budaya. Dengan begitu besarnya potensi yang ada di Desa Pemanis, POKDARWIS Pemanis Heritage memiliki peluang besar untuk berkembang menjadi daerah wisata alam dan budaya. Salah satu cara 
mempromosikan Pemanis Heritage adalah dengan pemanfaatan media sosial. Sayangnya hal itu belum dilakukan secara maksimal oleh POKDARWIS Pemanis Heritage.

Untuk itu perlu adanya pengutaan kompetensi fotografi, videografi dan tata kelola media promosi sosial media pada POKDARWIS Pemanis Heritage. Hal ini dapat dilakukan dengan mengadakan pelatihan fotografi, videografi dan tata kelola konten sosial media yang diikuti oleh anggota POKDARWIS Pemanis Heritage bersama dengan anggota Sekaa Teruta Teruni Swastika Taruna Desa Pemanis. Sekaa Teruna dipilih sebagai peserta selain anggota POKDARWIS Pemanis Heritage karena anggota Sekaa Teruna dinilai lebih mampu dan cakap teknologi dan sosial media, sehingga pengelolaan akun media sosial Pemanis Heritage dapat berkelanjutan.

Pelaksanaan pelatihan fotografi, videografi dan pengelolaan konten media sosal Pemanis Heritage dilakukan secara luring dan daring, mengingat adanya pandemi Covid-19 yang berimbas pada pelaksanaan PPKM yang mempengaruhi jadwal dan proses pelatihan. Kendati demikian, peneliti tetap berusaha menemukan solusi terbaik agar kegiatan PKM dapat terselenggara hingga tuntas.

\section{Saran}

Beberapa saran yang dapat peneliti sampaikan dalam pelaksanaan PKM pengutaan kompetensi fotografi, videografi dan tata kelola media promosi sosial media pada POKDARWIS Pemanis Heritage adalah: Diperlukan adanya kecerdasan sosial dalam masuk bermasyarakat di Desa seperti Desa Pemanis. Sifat masyarakatnya yang masih malu-malu bisa saja menyulitkan pelaksanaan PKM. Keberadaan mitra yang aktif sangat diperlukan dalam pelaksanaan PKM seperti ini. Peneliti perlu untuk selalu mencari informasi mengenai peraturan pencegahan pandemi yang dikeluarkan oleh pemerintah, sehingga bisa menjalankan PKM dengan menyesuaikan kegiatan dengan situasi di lapangan. Peneliti perlu berperan aktif dan berpikir cermat untuk mencari solusi apabila menemukan masalah di lapangan. Diperlukan adanya dorongan terus menerus dari Lembaga untuk tetap mengadakan kegiatan PKM sejenis di Desa-Desa selain Desa Pemanis. Masyarakat agar lebih membuka diri dalam menerima program-program seperti PKM di desanya demi kemajuan bersama. Masyarakat agar lebih menghargai potensi desa, dan mengembangkan potensi tersebut dengan berbagai cara, termasuk pengelolaan konten sosial media sebagai media promosi.

\section{DAFTAR RUJUKAN}

Asiani, Febri. (2019). Persuasive Copy Writing, Sebuah Seni Menjual Melalui Tulisan. Yogyakarta: Quadrant.

Ida, Rachmah. (2014). Metode Penelitian Studi Media dan Kajian Budaya. Jakarta: Kencana.

Soedjono, Soeprapto. (2006). Pot Pourri Fotografi. Jakarta: Penerbit Universitas Trisakti. 